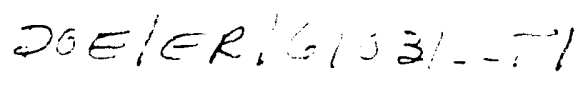

\title{
Controls over nutrient flow through plants and microbes in arctic tundra
}

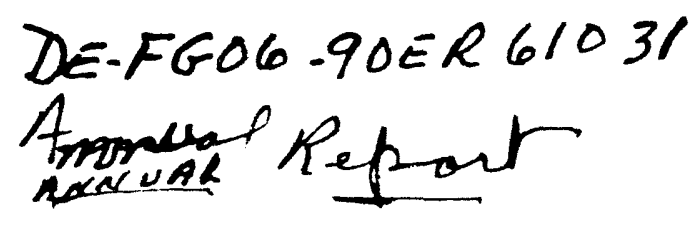

1990 Report on R4D Project.

\author{
Joshua P. Schimel \\ Inst. Arctic Biology \\ University of Alaska \\ Fairbanks, AK 99775
}

$\mathrm{DOE} / \mathrm{ER} / 61031--\mathrm{Tl}$

DE92 003435

\section{Introduction}

Plant growth in arctic tundra is generally strongly limited by nutrient availability, particularly by nitrogen. The purpose of this sub-project of the R4D program was to examine plant $\mathrm{N}$-uptake and the competition for $\mathrm{N}$ between plants and microbes in tundra. This competition can be an important control on $\mathrm{N}$-flow and plant uptake (Schimel et al. 1989) but its significance in tundra has not been studied intensively (Marion et al. 1982). How the factors controlling the outcome of competition are altered by disturbance has also received very limited study, yet this is an important facet of the R4D program.

The primary goal for this project in 1990 was to initiate studies on $\mathrm{N}$ partitioning and turnover in tussock tundra and how this is affected by dust deposition. Secondary goals were to 1) examine the effect of differential dust deposition on microbial activity and nutrient cycling processes (mineralization and nitrification), and 2) begin studies on the control of microbial $\mathrm{N}$-uptake.

The N-partitioning studies used ${ }^{15} \mathrm{~N}$ injected into Eriophorum tussocks to examine both the short-term (1 day) partitioning of $\mathrm{N}$ and the long-term (1 month and 1 year) redistribution of $\mathrm{N}$ through the plant-soil system. These experiments were done in both the early season (June) and peak season (July). To examine the

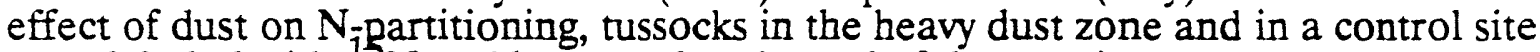
were labeled with ${ }^{15} \mathrm{~N}$ and harvested at the end of the growing season.

\section{Materials and Methods}

\section{$\mathrm{N}$-partitioning studies}

These studies were carried out in the Imnaviat Creek study site. An area approximately $25 \times 25 \mathrm{~m}$ was marked out and within that area 16 tussocks were identified that were approximately $15 \mathrm{~cm}$ in diameter and which were dominantly comprised of Eriophorum vaginatum, with only limited invasion by other vascular plant species.

The first experiment was started on June 17, 1990 with harvests on June 18 and July 17 1990. The second experiment was started on July 14 with harvests or. July 15 and August 181990.

To start the experiments, a wedge was cut from the tussock to measure initial moisture and $\mathrm{NH}_{4}{ }^{+}$concentrations. Then ${ }^{15} \mathrm{~N}$ labeled $\mathrm{NH}_{4} \mathrm{SO}_{4}$ was injected into the tussocks using a template to make injections as uniform as possible. The

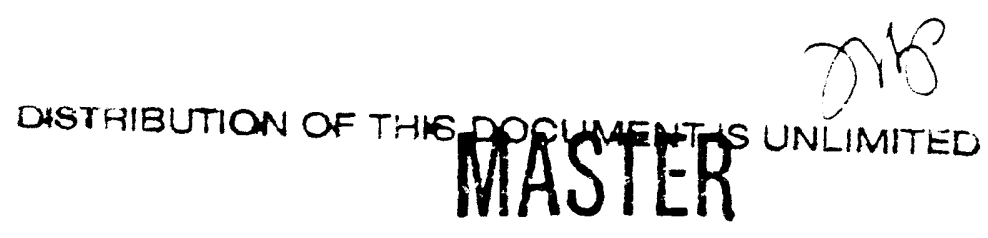


templates were $15 \mathrm{~cm}$ in diameter and contained 37 holes in a hexagonal array. The grid were arranged with a single hole in the center, and three concentric rings of holes containing 6,12 , and 18 holes around that. The injection procedure was different for each ring to account for the geometry of the tussock:

Innermost hole $-2 \mathrm{~mL}$, injected $1 \mathrm{ml}$ at $15 \mathrm{~cm}, 0.5 \mathrm{ml}$ just below the soil surface $(0$ $\mathrm{cm})$, and $0.5 \mathrm{~mL}$ halfway between the two.

1st ring- $1.5 \mathrm{~mL}, 0.5$ at $15 \mathrm{~cm}, 0.5$ at $0 \mathrm{~cm}$, and $0.5 \mathrm{~mL}$ half way between.

2nd ring $-1.0 \mathrm{~mL}, 0.5$ at $15 \mathrm{~cm}$ and $0.5 \mathrm{~mL}$ at $0 \mathrm{~cm}$.

3rd ring- $0.75 \mathrm{~mL}, 0.375$ at $15 \mathrm{~cm}$ and $0.5 \mathrm{~mL}$ at $0 \mathrm{~cm}$.

At each harvest date, wedges were cut from the tussocks and these were subsampled to measure total $\mathrm{N}$ and ${ }^{15} \mathrm{~N}$ in the following pools:

$\mathrm{NH}_{4}$

Eriophorum vaginatum shoots

Eriophorum vaginatum rhizomes

Eriophorum vaginatum roots

Other live plant material

Dead shoots and stem bases

Soil

Microbial biomass

\section{Effect of dust on $\mathrm{N}$-partitioning}

These experiments were carried out similarly to the above experiments, except that they were carried out at the dust plots established by Drs. Skip and Marilyn Walker. We selected 6 tussocks at random at $20 \mathrm{~m}$ from the haul road (dust treatment) and at $400 \mathrm{~m}$ from the road (control).

\section{Effect of road dust on microbial activity}

Samples of tussock and intertussock soil were taken at 10,25,50,100, and $400 \mathrm{~m}$ from the haul road. These were taken near to the official vegetation quadrats. These samples were returned to the lab and frozen until experiments could be performed on them. Analyses being done include microbial respiration and $\mathrm{N}$ mineralization/immobilization.

\section{Results}

Results are currently available for the ${ }^{15} \mathrm{~N}$ partitioning studies on the June injection experiment. Table 1 shows the proportion of the recovered ${ }^{15} \mathrm{~N}$ found in each component. 
Table 1. Proportion of recovered ${ }^{15} \mathrm{~N}$ in each pool

Component
Shoots
Rhizomes
Roots
Other plants
Dead
Soil

\begin{tabular}{c}
1 day \\
\%o of recovered \\
\hline $0.48(0.14)$ \\
$1.15(0.33)$ \\
$1.42(0.33)$ \\
$0.74(0.32)$ \\
$23.81(7.47)$ \\
$72.40(7.62)$
\end{tabular}

1 month

$\%$ of recovered

$1.35(0.39)$

$1.03(0.30)$

$1.54(0.29)$

$1.30(0.24)$

$24.97(6.64)$

$69.80(6.77)$

* S.E. of 8 replicate tussocks.

Less than $4 \%$ of the ${ }^{15} \mathrm{~N}$ recovered after one day was in living plants. This value is very low compared to studies on $\mathbf{N}$ in other ecosystems (plants in $\mathbf{N}$-limited California grassland take up $\approx 15 \%$ of available $N$; Jackson et al. 1989; Schimel et al. 1989 ) and on $\mathrm{P}$ in tussock tundra (plants take up $\approx 10 \%$ of $32 \mathrm{P}$ recovered; Jonasson and Chapin, 1990). These results demonstrate that tundra soil microbes are very effective at competing for nitrogen, and suggests that microbes are strongly $\mathrm{N}$ limited.

The large proportion of ${ }^{15} \mathrm{~N}$ recovered in dead material is almost certainly due to some of this material being below what was defined as the "soil surface" for the injection protocol. This also suggests that there was very little downward leaching of the label.

There was very little movement of the label between the various components of the plant/soil system. This may suggest that very little $\mathrm{N}$ is remobilized over one month. However, since so little of the applied $\mathrm{N}$ was taken up by plants after one day, it would take very rapid turnover of the soil $\mathrm{N}$ to allow plants to accumulate a significantly larger portion of the recovered $\mathrm{N}$. Total ${ }^{15} \mathrm{~N}$ in plants increased from $3.79 \%$ of recovered to $5.22 \%$. These numbers can be used to estimate the proportional turnover of the soil immobilized $\mathrm{N}$ :

$\%$ Turnover $=\quad \frac{\Delta \text { recovered }}{\% \text { taken up by plants in } 1 \text { day }} \times 100$

This calculation suggests that $\approx 38 \%$ of the ${ }^{15} \mathrm{~N}$ immobilized in the soil may have been turned over in one month, giving an estimate of soil microbial-N turnover on the order of once per growing season. This calculation is based on a marginally significant increase and therefore has a large degree of uncertainty. The extent of $\mathrm{N}$ turnover through soil microbes needs to be estimated to a higher degree of certainty.

There was a significant increase in the ${ }^{15} \mathrm{~N}$ in Eriophorum shoots and some increase in other vegetation. As the amount of $15 \mathrm{~N}$ recovered in roots and rhizgmes was unchanged, it suggests that there was some remobilization and uptake of ${ }^{15} \mathrm{~N}$ over the course of one month.

We are still waiting for ${ }^{15} \mathrm{~N}$ data on other samples, and other lab experiments are still underway. More complete results are therefore not yet available. 


\section{References}

Jackson, L.E., J.P. Schimel, and M.K. Firestone. 1989. Short-term partitioning of ammonium and nitrate between plants and microbes in an annual grassland. Soil Biol. Biochem. 21:409-415.

Jonasson, S, and F. S. Chäpin III. 1990. Seasonal uptake and allocation on phosphorus in Eriophorum vaginatum, measured by labelling with 32P. Ecology. Submitted.

Marion, G.M., P.C. Miller, J. Kummerow, and W.C. Oechel. 1982. Competition for nitrogen in a tussock tundra ecosystem. Plant and Soil 66: 317-327

Schimel, J.P., L.E. Jackson, and M.K. Firestone. 1990. Spatial and temporal effects on plant-microbial competition for inorganic nitrogen in a California annual grassland. Soil Biol. Biochem. 21:1059-1066.

\section{DISCLAIMER}

\footnotetext{
This report was prepared as an account of work sponsored by an agency of the United States Government. Neither the United States Government nor any agency thereof, nor any of their employees. makes any warranty, express or implied, or assumes any legal liability or responsibility for the accuracy, completeness, or usefulness of aniy information, apparatus, product, or process disclosed, or represents that its use would not infringe privately owned rights. Reference herein to any specific commercial product, process, or service by trade name, trademark, manufacturer. or otherwise does not necessarily constitute or imply its endorsement, recommendation, or favoring by the United States Government or any agency thereof. The views and opinions of authors expressed herein do not necessarily state or reflect those of the United States Government or any agency thereof
} 

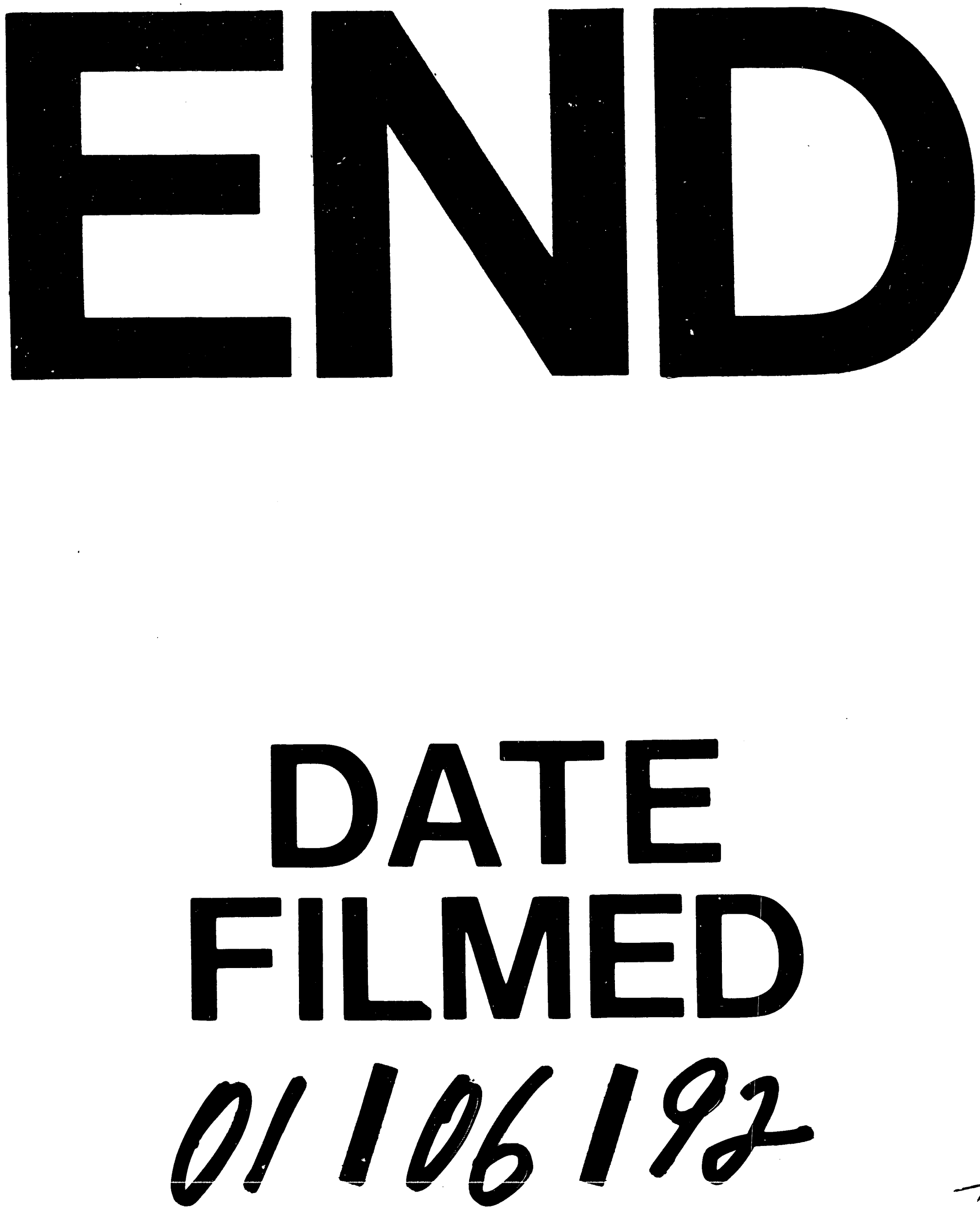
